\title{
Michał Rogoz
}

\section{Muminki Tove Jansson na polskim rynku wydawniczym}

\section{Wprowadzenie}

\begin{abstract}
Cykl opowieści o Muminkach jest jedną z bardziej znanych lektur dla dzieci powstałych w Finlandii, a jego autorkę ${ }^{1}$ nierzadko sytuuje się w kręgu tak wybitnych twórców nordyckiego obszaru kulturowego, jak Hans Christian Andersen (Dania) czy Astrid Lindgren (Szwecja) ${ }^{2}$. Historyjki te zaczęły powstawać pod koniec lat 30 . XX w. W zamyśle samej pisarki i ilustratorki miały stanowić swoiste remedium na smutną rzeczywistość okresu wojennego:
\end{abstract}

Była zima 1939 roku, czas wojny ${ }^{3}$. Praca stała w miejscu; miało się uczucie, że każda próba stworzenia obrazu rzeczywistości jest całkowicie niepotrzebna. Może więc nic dziwnego, że ogarnęła mnie chęć napisania czegoś, co zaczynałoby się od „Był sobie kiedyś”. Dalszy ciąg musiał być oczywiście bajką, tego nie dało się uniknąć, ale zrezygnowałam z książąt, księżniczek i małych dzieci, wybierając na ich miejsce

1 Tove Marika Jansson (1914-2001) - szwedzkojęzyczna pisarka fińska, malarka i ilustratorka.

2 Por. R. Kuivasmäki, Nordycki kwartet baśniowy, tłum. E. Świerżewska, „Guliwer” 2002, nr 4, s. 5-11.

3 Mowa tu o tzw. wojnie zimowej (30.11.1939-13.03.1940), konflikcie zbrojnym między Finlandią a ZSRR. 
gniewną figurkę, którą sygnowałam rysunki satyryczne i którą nazwałam Muminkiem4.

Jak słusznie zauważa Katarzyna Iwanicka, kreacja plastyczna poprzedziła sam zamysł stworzenia opowieści ${ }^{5}$.

Za polskiego „odkrywcę” tych utworów uznaje się Wojciecha Żukrowskiego, który w latach 60. gościł w Finlandii, gdzie naocznie przekonał się o ich niezwykłej popularności. Stamtąd też przywiózł angielskojęzyczne edycje książek Tove Jansson i zarekomendował je do druku w Wydawnictwie „Nasza Księgarnia”. Po latach opowiedział o tym zdarzeniu czytelnikom „Płomyka”:

Pytacie, jak dostały się Muminki do Polski? Kiedy przyjechałem do Finlandii, dostałem kilka z nich od moich przyjaciół jako maskotki do powieszenia $\mathrm{w}$ aucie, zwłaszcza podobał mi się ów dobroduszny skrzat z mordką hipopotama. [...] Potem zobaczyłem je na półkach bibliotek, ustawione $\mathrm{w}$ gromadkę przyglądały mi się wybałuszonymi oczyskami. [...] Zdumiałem się ich popularnością. I wtedy powiedziano mi, że są to bohaterowie cyklu powieściowego pani Tove Jansson? .

\section{Polskie edycie w vjęciu historyczno-statystycznym}

Na polskim rynku wydawniczym postacie te są obecne od 1964 r., kiedy to pod auspicjami Wydawnictwa „Nasza Księgarnia” ukazała się książeczka $W$ Dolinie Muminków ${ }^{8}$. Ta specjalizująca się w literaturze dziecięcej oficyna do dziś ma monopolistyczną pozycję w zakresie edycji oryginalnego skandynawskiego cyklu, choć w ostatnich latach inicjatywy wydawnicze nawiązujące do postaci Muminków podjęły także inne firmy9

${ }^{4}$ T. Jansson, Małe trolle i duża powódź, tłum. T. Chłapowska, Warszawa 2006, s. 5.

${ }^{5}$ K. Iwanicka, Tove Jansson jako ilustratorka Muminków, [w:] Świat Muminków. Materiały z sesji literackiej, Gdańsk, 26-27 maja 1994, pod red. M. Hempowicz, Gdańsk 1995, s. 100 .

6 I. Bolek, Tove Jansson, „Nowe Książki” 1977, nr 11, s. IV (okładka).

7 W. Żukrowski, Jak dostały się Muminki do Polski?, „Płomyk” 1974, nr 6, s. 161.

8 T. Jansson, W Dolinie Muminków, tłum. I. Wyszomirska, Warszawa 1964.

9 Na przykład „Egmont”, Świat Książki (Bertelsmann Media Polska), TM Semic, Wilga, Wydawnictwo Literackie. Szerzej na ten temat w dalszej części artykułu. 
Opowiadania T. Jansson cieszą się w naszym kraju niesłabnącą popularnością, szczególnie wyraźnie widoczną od początku lat 70., co potwierdzają wielotysięczne nakłady ${ }^{10}$ oraz duża liczba wznowień (tab. 1). Najczęściej wydawano książeczkę W Dolinie Muminków (16 razy), ale niewiele mniejszą liczbę edycji miały takie pozycje, jak Zima Muminków i Opowiadania z Doliny Muminków (15) czy Lato Muminków (14) ${ }^{11}$. Cykl opowieści o sympatycznych mieszkańcach skandynawskiej doliny obejmuje osiem tomów ${ }^{12}$, jednak także innym utworom T. Jansson nawiązującym do postaci z tej literackiej baśni nierzadko nadawano podobną szatę graficzną (np. Małe trolle i duża powódź13 czy też opublikowana w $2008 \mathrm{r}$. kompilacja - Mądrości z Doliny Muminków ${ }^{14}$ ).

Poszczególne opowiadania ukazywały się w Polsce w kolejności odmiennej niż porządek założony przez autorkę. I tak, rozpoczynająca właściwą opowieść książeczka Kometa nad Dolinq Muminków miała swój polski debiut dopiero w 1977 r. Rok później opublikowano po raz pierwszy Pamiętniki Tatusia Muminka (28 lat po szwedzkojęzycznym pierwodruku), wreszcie w 1980 r. pojawił się zamykający cykl tom Dolina Muminków w listopadzie (10 lat po premierze w Finlandii). Dopiero w $1995 \mathrm{r}$. - 50 lat po pierwodruku - wydano książkę, od której w zasadzie wszystko się zaczęło: Småtrollen och den stora översvämningen, przetłumaczoną na język polski jako Małe trolle i duża powódź15. Brak w tytule określe-

${ }^{10}$ Do 1989 r. nakłady poszczególnych części cyklu wynosiły od ok. 20 do 50 tys. egz. Jedynie Pamiętniki tatusia Muminka ukazały się w 1989 r. w ponad 100 tys. egz. Po 1989 r. nie podawano w stopkach wydawniczych takich informacji, gdyż na wolnym rynku są one objęte tajemnicą handlową. Według danych Biblioteki Narodowej nakład całkowity poszczególnych części cyklu do 2008 r. włącznie wynosił od 163 tys. egz. w przypadku tomiku Tatuś Muminka i morze do 231 tys. egz. w przypadku tomiku Opowiadania z Doliny Muminków. Zob. „Ruch Wydawniczy w Liczbach” 2008, s. 117-118. Zapewne jednak w obliczeniach tych nie uwzględniono kilku edycji, które zostały pominięte przez „Przewodnik Bibliograficzny. Urzędowy Wykaz Druków Wydanych w Rzeczypospolitej Polskiej”.

11 Stan na dzień 31 grudnia $2010 \mathrm{r}$.

12 Por. J. Papuzińska, Muminki, [w:] Słownik literatury dziecięcej i młodzieżowej, pod red. B. Tylickiej, G. Leszczyńskiego, Wrocław 2002, s. 255. „Nasza Księgarnia” sprzedaje jednak cykl jako komplet dziewięciu książeczek, dołączając tom Małe trolle i duża powódź.

13 T. Jansson, Małe trolle i duża powódź, tłum. T. Chłapowska, Warszawa 2006.

14 Taż, Mądrości z Doliny Muminków, tłum. T. Chłapowska, I. Szuch-Wyszomirska, Warszawa 2008.

15 W literaturze przedmiotu funkcjonowały wcześniej inne tłumaczenia tego tytułu, np. Małe skrzaty i wielka fala, zob. K. Laitinen, S. Apo, Historia literatury fińskiej, tłum. C. Lewandowska, Wrocław 1991, s. 247; Małe trolle i wielka powódź - A. Romanowska, Na poczq̨tku był potop, „Nowe Książki” 1995, nr 9, s. 64. 
nia „Muminki” sugeruje swoistą „inność” tej pozycji, co dodatkowo zdają się potwierdzać autorskie ilustracje - tytułowe trolle mają na nich nieco odmienny wygląd ${ }^{16}$.

Tabela 1. Książki Tove Jansson z postaciami z cyklu o Muminkach na polskim rynku wydawniczym ${ }^{17}$

\begin{tabular}{|c|c|c|c|c|}
\hline Tytuł & $\begin{array}{l}\text { Data } \\
\text { pierwszego } \\
\text { wydania } \\
\text { oryg. }\end{array}$ & $\begin{array}{l}\text { Liczba } \\
\text { wydań } \\
\text { polskich }\end{array}$ & Daty wydań polskich & $\begin{array}{c}\text { Oficyna } \\
\text { wydawnicza }\end{array}$ \\
\hline $\begin{array}{l}\text { Małe trolle i duża } \\
\text { powódź }\end{array}$ & 1945 & 8 & $\begin{array}{l}\text { 1995, 1997, 1998, } 1999, \\
\text { 2003, 2006, 2007, } 2010\end{array}$ & $\begin{array}{l}\text { „Nasza } \\
\text { Księgarnia” } \\
\text { (dalej: NK) }\end{array}$ \\
\hline $\begin{array}{l}\text { Kometa nad Doling } \\
\text { Muminków }\end{array}$ & $1946^{*}$ & 14 & $\begin{array}{l}\text { 1977, 1988, 1990, 1994, } \\
\text { 1995, 1997, 1998, 1999, } \\
\text { 2000, 2003, 2005, 2006, } \\
2007,2010\end{array}$ & NK \\
\hline $\begin{array}{l}\text { W Dolinie } \\
\text { Muminków }\end{array}$ & 1948 & 16 & $\begin{array}{l}\text { 1964, 1972, 1975, 1981, } \\
\text { 1990, 1993, 1995, 1997, } \\
\text { 1998, 1999, 2000, 2003, } \\
2005,2006,2007,2010\end{array}$ & NK \\
\hline $\begin{array}{l}\text { Pamiętniki Tatusia } \\
\text { Muminka }\end{array}$ & 1950 & 12 & $\begin{array}{l}\text { 1978, 1989, 1990, 1994, } \\
\text { 1997, 1998, 1999, 2000, } \\
\text { 2002, 2003, 2006, } 2007\end{array}$ & NK \\
\hline Lato Muminków & 1954 & 14 & $\begin{array}{l}\text { 1967, 1972, 1975, 1985, } \\
\text { 1990, 1994, 1996, 1998, } \\
\text { 1999, 2000, 2004, 2006, } \\
2007,2008\end{array}$ & NK \\
\hline Zima Muminków & 1957 & 15 & $\begin{array}{l}\text { 1969, 1972, 1975, 1986, } \\
\text { 1990, 1994, 1997, 1998, } \\
\text { 1999, 2000, 2002, 2006, } \\
2007,2008,2010\end{array}$ & NK \\
\hline $\begin{array}{l}\text { Opowiadania } \\
\text { z Doliny Muminków }\end{array}$ & 1962 & 15 & $\begin{array}{l}\text { 1970, 1973, 1975, 1987, } \\
\text { 1990, 1994, 1997, 1998, } \\
\text { 1999, 2000, 2003, 2006, } \\
2007,2008,2010\end{array}$ & NK \\
\hline
\end{tabular}

16 Por. A. Romanowska, dz. cyt., s. 64; J. Olech, Mądra jak sowa, „Magazyn Gazety Wyborczej" 2001, nr 190, s. 33.

17 Wytłuszczonym drukiem oznaczono pierwsze polskie wydania książkowe, pogrubioną linią tabeli wyróżniono serię ośmiu właściwych książeczek cyklu przedstawiających przygody Muminków. 
Tabela 1. Książki Tove Jansson z postaciami z cyklu o Muminkach na polskim rynku wydawniczym (ciąg dalszy)

\begin{tabular}{|c|c|c|c|c|}
\hline $\begin{array}{l}\text { Tatuś Muminka } \\
\text { i morze }\end{array}$ & 1965 & 11 & $\begin{array}{l}\text { 1977, 1988, 1990, 1994, } \\
\text { 1997, 1998, 1999, 2003, } \\
\text { 2006, 2007, } 2010\end{array}$ & NK \\
\hline $\begin{array}{l}\text { Dolina Muminków } \\
\text { w listopadzie }\end{array}$ & 1970 & 12 & $\begin{array}{l}\text { 1980, 1988, 1990, 1994, } \\
\text { 1997, 1998, 1999, 2000, } \\
2002,2006,2007,2010\end{array}$ & NK \\
\hline $\begin{array}{l}\text { Co zdarzyło się } \\
\text { potem? }\end{array}$ & 1952 & 0 & - & - \\
\hline $\begin{array}{l}\text { Kto pocieszy } \\
\text { Maciupka? }\end{array}$ & 1960 & 1 & 1980 & NK \\
\hline $\begin{array}{l}\text { Niebezpieczna } \\
\text { podróż }\end{array}$ & 1977 & 1 & 1986 & NK \\
\hline $\begin{array}{l}\text { Łobuz w domu } \\
\text { Muminków }\end{array}$ & 1980 & 1 & 2001 & $\begin{array}{l}\text { „Magazyn } \\
\text { Rzeczpospo- } \\
\text { litej” }\end{array}$ \\
\hline $\begin{array}{l}\text { Mądrości z Doliny } \\
\text { Muminków }^{* *}\end{array}$ & 2002 & 1 & 2008 & NK \\
\hline $\begin{array}{l}\text { Mądrości Mamy } \\
\text { Muminka }\end{array}$ & - & 1 & 2010 & $\begin{array}{l}\text { Wydawnictwo } \\
\text { Literackie } \\
\text { (dalej: WL) }\end{array}$ \\
\hline $\begin{array}{l}\text { Mądrości Tatusia } \\
\text { Muminka }\end{array}$ & - & 1 & 2010 & WL \\
\hline Mądrości Muminka & - & 1 & 2010 & WL \\
\hline
\end{tabular}

* Nowa wersja tej książki ukazała się następnie w 1968 r. Jest ona podstawą polskiego tłumaczenia.

** Tekst stanowi zbiór sentencji i fragmentów opowieści o Muminkach pochodzących z ośmiu tomów serii.

Źródło: ustalenia własne na podstawie „Przewodnika Bibliograficznego. Urzędowego Wykazu Druków Wydanych w Rzeczypospolitej Polskiej”, Narodowego Uniwersalnego Katalogu Centralnego (NUKAT) oraz Katalogu Rozproszonego Bibliotek Polskich (KaRo) ${ }^{18}$.

${ }^{18}$ Jako ciekawostkę należy odnotować fakt, że niektóre edycje odnalezione za pośrednictwem NUKAT oraz KaRo, a następnie poddane weryfikacji z autopsji, nie zostały zarejestrowane w bieżącej bibliografii narodowej. 


\section{Thumaczenia}

Tłumaczem pierwszych czterech polskich wydań była Irena Szuch-Wyszomirska - znana z pierwszego przekładu Pippi Langstrump noszącego kontrowersyjny tytuł Fizia Pończoszanka. W przypadku Muminków jej tłumaczenie nie wywołało takich dyskusji, choć pojawiały się głosy o niefortunnej nazwie głównych bohaterów kojarzących się z „mumiami”19. Nazwa ta, wbrew opiniom niektórych krytyków, szybko rozpowszechniła się w naszym kraju. Warto przy tym zauważyć, że występuje ona, inaczej niż w szwedzkiej wersji, we wszystkich tytułach polskojęzycznego cyklu. Tłumacząc imiona postaci, zastosowano niejednolitą metodę, nadając niektórym z nich swojsko brzmiące nazwy, np. Włóczykij, Ryjek, Panna Migotka, a część pozostawiając w formie oryginalnej, np. Hatifnatowie, Yng, Too-tiki ${ }^{20}$. W latach 70., po śmierci pierwszej translatorki, wyłączność na przekład uzyskała Teresa Chłapowska, zaprzyjaźniona z samą autorką oraz jej bratem. Tłumaczka ta podążyła utartym tropem, starając się zachować podobny, możliwie najbliższy założeniom T. Jansson, styl opowieści. Paweł Huelle zauważa drobną zmianę w nazwie postaci: obecny w pierwszym wydaniu Gapinder w nowszej wersji został nazwany Paszczakiem $^{21}$. Choć $w$ wypowiedziach bohaterów jest stosunkowo niewiele charakterystycznych słów, a ich indywidualność przejawia się raczej w wyglądzie, rysie charakterologicznym czy sposobie postrzegania rzeczywistości, to jednak pewien odzew w komentarzach prasowych znalazło nadużywanie przez Muminka wyrażenia „E tam” (we wcześniejszych wydaniach pisane „Etam”) 22. Należy jednak zaznaczyć, że krytycy na ogół życzliwie odnosili się do obu wersji tłumaczeńn ${ }^{23}$.

19 J. Żylińska, Glosy do Anny Kamieńskiej „Traktatu o historii Muminków”, „Twórczość” 1971, nr 8, s. 162. Nazwa „Muminek” nie jest wynikiem fantazji tłumaczki, co „podejrzewała” choćby A. Kamieńska, autorka eseju Traktat o historii Muminków, ale wierną kopią fińskiego Muumin. Tym trollem-łasuchem ponoć straszył małą Tove jej wuj Einar, por. K. Maidt-Zinke, Anarchiczny potencjał „Muminków”, „Forum” 1994, nr 36, s. 16; W. Cejrowski, Dolina Tove, „Rzeczpospolita” 2001, nr 203, dodatek „Magazyn”, s. 15.

20 Oryginalnym wkładem w onomastykę jest Buka (szwedzkie Mörrön, co można przetłumaczyć jako „panika”).

21 P. Huelle, Dom na skraju łąki, „Tygodnik Powszechny” 2007, nr 15, s. 17.

${ }^{22}$ J. Hartwig-Sosnowska, One istnieja na pewno, "Nowe Książki” 1978, nr 24, s. $19-21$.

${ }^{23}$ T. Brzeska-Smerkowa, Muminki w polskiej krytyce literackiej, [w:] Świat Muminków..., s. 38. 


\section{Szata graficzna}

Polskim wkładem w szatę graficzną były oryginalnie stylizowane okładki. W latach 1964-2010 ich autorskie projekty wykonało aż siedmiu ilustratorów. Pierwszą edycję ozdobiła Krystyna Witkowska, kolejne trzy z lat 1967-1970 zostały zaprojektowane przez Ewę Walawską. Jej koncepcja plastyczna, stylizowana na dziecięcą kompozycję, została przygotowana z wykorzystaniem dużej płaskiej plamy, kulisowej perspektywy oraz deformacji postaci. Interesująco rozwiązany krój liter przypomina wycinankę ${ }^{24}$. W latach 70 . przyjęła się charakterystyczna dla wielu późniejszych wydań forma niewielkiej książeczki o kształcie zbliżonym do kwadratu, z kolorowym rysunkiem na okładce nawiązującym do zawartości tomu. Do tego designu wrócono również we wznowieniach powstałych w XXI w. Specyficzny, refleksyjny charakter opowieści starano się oddać przez zastosowanie stonowanej, pastelowej kolorystyki. Postacie przedstawiano na tle baśniowego pejzażu, z wykorzystaniem naturalnych elementów przyrody, takich jak góry ${ }^{25}$ czy bezkresne morza ${ }^{26}$. Obecny na okładce obrazek stanowił z reguły wariację na temat wybranej śródtekstowej ilustracji. Dość kontrowersyjny element projektu stanowiła forma tytułu, wyróżniająca się brakiem majuskuły. Powstały w ten sposób błąd ortograficzny ${ }^{27}$ usunięto dopiero w późniejszych wydaniach opartych na tym samym schemacie kompozycyjnym, w którym Mirosław Tokarczyk dokonał tylko niewielkiego retuszu liternictwa ${ }^{28}$. W latach 90. pojawił się nowy układ graficzny serii autorstwa Marii Turbaczewskiej. Na okładkach wykorzystano motywy ilustracyjne z polskiej wersji filmowej Muminków przygotowanej przez studio Se-ma-for w latach 1977-1982.

Rysunki w tekście pozostawały we wszystkich kolejnych wydaniach czarno-białe, przy czym już od pierwszych edycji występowały zarówno większe kompozycje graficzne wykonane jedynie z użyciem kreski, zajmujące najczęściej trzy czwarte strony ${ }^{29}$, jak i niewielkie „ozdobniki” two-

${ }^{24}$ Por. np. T. Jansson, W Dolinie Muminków, tłum. I. Wyszomirska, Warszawa 1964.

25 Por. taż, Zima Muminków, tłum. I. Szuch-Wyszomirska, Warszawa 1986.

${ }^{26}$ Por. taż, Tatuś Muminka i morze, tłum. T. Chłapowska, Warszawa 1977.

${ }^{27}$ Aby pozostać w zgodzie z zasadami polskiej ortografii, przy zapisie pierwszego wyrazu tytułu nieodzowne było stosowanie majuskuły.

${ }^{28}$ Por. np. T. Jansson, Kometa nad Dolinq Muminków, tłum. T. Chłapowska, Warszawa 2006.

${ }^{29}$ Por. taż, Tatuś Muminka i morze..., s. 111, 150, 212. 
rzące nagłówki poszczególnych rozdziałów ${ }^{30}$. Uwagę zwraca stylizacja na grafikę drzeworytową oraz umiejętne operowanie światłocieniem ${ }^{31}$. Ilustracje T. Jansson stanowiły integralną część opowieści, zachwycając swą dynamiką, ekspresją i komizmem sytuacyjnym. Jak słusznie zauważył jeden z krytyków, istnieje tu specyficzny, intymny związek między rysunkami a tekstem ${ }^{32}$. Szkice portretowe stanowiły wzorzec stylistyczny poszczególnych postaci, rozpowszechniony później w ekranizacjach tej baśni. Poszczególne tomy zostały zaopatrzone w autorskie mapy miejsca akcji, przypominające średniowieczne sztychy. Premierowe w Polsce opowiadanie $W$ Dolinie Muminków zawiera szkic tytułowej krainy, dodatkowo uzupełniony planem domu Muminków w postaci dwóch pionowych rzutów parteru i piętra ${ }^{33}$. Wydanie Zimy Muminków poprzedza mapa terenu literackiej akcji, tym razem w śniegowym entourage' $u^{34}$. Podobny szkic w większej skali, obejmujący całe baśniowe wybrzeże, otwiera ostatnią książeczkę z serii - Dolina Muminków w listopadzie. W tomie Lato Muminków pojawia się kartograficzny obraz Zatoki Jodłowej z takimi elementami, jak Teatr na Mieliźnie, Więzienie czy domy Filifionki i Paszczakówny ${ }^{35}$. W książce Tatuś Muminka i morze można obejrzeć dwie mapy: pierwszą przedstawiającą teatrum wydarzeń, czyli niewielką wyspę z latarnią morską w Zatoce Fińskiej ${ }^{36}$, oraz drugą zamieszczoną w tekście, prezentującą „naukowy” schemat autorstwa Tatusia Muminka tłumaczący fenomen znikającej wody w jeziorze ${ }^{37}$. W 2007 r. pojawił się na rynku tomik zatytułowany Opowiadania z Doliny Muminków o charakterze kolekcjonerskim, w twardej okładce ukazującej postaci Muminka i Homka.

30 Tamże, s. 5, 87, 117, 156, 301.

${ }^{31}$ K. Iwanicka, Tove Jansson jako ilustratorka Muminków..., s. 101.

32 D. Mazur, W stronę staroświeckiej harmonii, „Przegląd Artystyczno-Literacki” 2000, nr 3, s. 171.

${ }^{33}$ Por. T. Jansson, W Dolinie Muminków, tłum. I. Szuch-Wyszomirska, Warszawa 1995, s. 2.

34 Taż, Zima Muminków..., s. 2.

35 Taż, Lato Muminków, tłum. I. Szuch-Wyszomirska, Warszawa 1999, s. 2.

36 Taż, Tatuś Muminka i morze..., s. 2.

37 Tamże, s. 235. 


\section{Nawiq̨zania i kontynuacje}

Oprócz zasadniczej serii z postaciami Muminków jest także związanych kilka innych utworów T. Jansson, w których pojawiają się bohaterowie interesującego nas cyklu. W krótkiej, przeznaczonej dla młodszych dzieci historyjce o Maciupku poszukującym przyjaciela występują znane z malowniczej doliny postacie: Paszczak, Filifionka, Homek czy budząca strach Buka $^{38}$. Podobnym, bogato ilustrowanym opowiadaniem jest Niebezpieczna podróż, w której świat Muminków poznajemy oczyma głównej bohaterki Zuzanny ${ }^{39}$. Oba wymienione utwory ukazały się w niewielkich nakładach w „Naszej Księgarni” w latach 80., do tej pory brakuje natomiast polskiego wydania książki T. Jansson Hur gick det sen? (Co zdarzyło się potem? $)^{40}$. W 2001 r. w „Magazynie Rzeczpospolitej” opublikowano utwór Łobuz w domu Muminków (w przekładzie Teresy Chłapowskiej), opowiadanie o piracie Bobku - dziwnym przybyszu i „zatajonym znajomym” Tatusia Muminka ${ }^{41}$. Jak dotąd, nie doczekało się ono samoistnej edycji książkowej.

W 1953 r. pojawiły się komiksy oparte na fabule Muminków. Ukazywały się one w długim cyklu na łamach angielskiego czasopisma „The Evening Post”, rysunki wykonywali do spółki Tove Jansson oraz jej brat Lars. Serię tę postanowiło udostępnić polskim czytelnikom Wydawnictwo „Egmont”. W latach 2005-2007 opublikowano osiem kolejnych zeszytów: Nowy dom Maminka, Muminki i morze, Wyspa Muminków, Muminki i Marsjanie, Tatuś Muminka i szpiedzy, Muminki na riwierze, Zabawa w udawanie i Lampa Muminka. Opracowano także zbiorcze edycje łączące kilka historyjek. Prasa zamieszczała liczne omówienia poszczególnych odcinków cyklu ${ }^{42}$. W 2006 r. to samo wydawnictwo rozpoczęło publikację ksią-

38 T. Jansson, Kto pocieszy Maciupka?, tłum. T. Chłapowska, Warszawa 1980.

39 Taż, Niebezpieczna podróż, tłum. T. Chłapowska, Warszawa 1986.

40 Skądinąd powstało robocze tłumaczenie tego tekstu (T. Chłapowska) na potrzeby spektaklu teatralnego, zob. I. Bolek, dz. cyt., s. IV (okładka); Muminki a sprawa polska, „Guliwer" 1994, nr 2, s. 45.

41 T. Jansson, Łobuz w domu Muminków, tłum. T. Chłapowska, „Rzeczpospolita” 2001, nr 203 - dodatek, s. 12-17.

42 Por. D. Makówka, Rysunki z Doliny Muminków, „Rzeczpospolita” 2006, nr 45, s. 14; A. Kłoś, Powrót białych trolli, „Gazeta Wyborcza. Stołeczna” 2005, nr 271, s. 8; K. Ł., Dolina Muminków w obrazkach, „Kurier Poranny” 2006, nr 15, s. 9; K. Wachowiak, Muminki w obrazkach, „Słowo Polskie. Gazeta Wrocławska” 2005, nr 272; „Tygodnik Powszechny” 2006, nr 5 - dodatek „Książki w Tygodniku”, s. 21; K. Ł., Bilet do magicznej doliny, „Kurier Poranny" 2007, nr 63, s. 10. 
żeczek z obrazkami autorstwa Haralda Sonessona inspirowanych tekstami i rysunkami T. Jansson. W ramach tego przedsięwzięcia przygotowano dziewięć pozycji (Tatuś Muminka na rybach, Muminki i niespodzianka, Muminki w cyrku, Śnieżny poranek Muminka, Wyprawa odkrywców, Muminek w lesie, Muminek wpada do wody, Muminek detektyw, Muminek szuka drogi do domu). „Egmont” był również wydawcą kolorowanek wykorzystujących postacie Muminków, kilku książeczek wyklejanek oraz niewielkich albumików z kartonowymi stronami, przeznaczonymi dla młodszych dzieci. Warto jednak zauważyć, że postaci Muminków pojawiły się w komiksowej wersji w Polsce już w końcu XX w., ponad 10 lat przed sygnowaną przez „Egmont”, opartą na rysunkach Tove i Larsa Janssonów, serią. W latach 1993-1994 ówczesny potentat na rynku książeczek obrazkowych TN Semic wydał, w ukazujących się co miesiąc zeszytach, 13 kolejnych odcinków historyjek o Muminkach uzupełnionych o łamigłówki adresowane do dzieci. Z kolei Wydawnictwo „Wilga” przygotowało w 2010 r. przeznaczone dla pierwszoklasistów broszury, służące nauce czytania i liczenia: Muminki - mała księga słowa, Muminki - mała księga liczby. Oprócz tego w serii tej ukazała się kolorowanka i wyklejanka oraz krótki, 28-stronicowy tomik beletrystyczny, nawiązujący do fabuły bajki rysunkowej.

Liczne przedsięwzięcia „okołomuminkowe” powstały również pod auspicjami „Naszej Księgarni”. Już w 1995 r. ten znany wydawca literatury dla młodego czytelnika stworzył serię książeczek obrazkowych opartych na twórczości T. Jansson. Ukazało się 10 zeszytów: Czemu się martwisz mamusiu?, Ostatni smok na świecie, Zaczarowane obłoczki, Paszczaku coś ty zrobił, Wielka wyprawa, Niewidoczne dziecko, Zima i czary, Koniec świata, Prezent urodzinowy, Spacer czarownicy, oraz tomy zbiorcze obejmujące po kilka opowieści z tego cyklu. W tekstach tych wykorzystano pomysły T. Jansson przede wszystkim co do kreacji bohaterów, wyposażonych w specyficzne rysy psychologiczne. Stronę plastyczną przygotował znany z projektów okładek do właściwej serii o Muminkach Mirosław Tokarczyk, natomiast same opowiadania napisali: Elżbieta Brzoza, Grażyna Kościuch i Jerzy Martin. Mimo nie zawsze przychylnych recenzji ${ }^{43}$ seria ta cieszyła się sporą popularnością, o czym świadczą trzy kolejne jej edycje w latach 1995, 1998 i 2007. Jej swoistą kontynuację stanowił bogato ilustrowany, wydany w twardej okładce wolumin Muminkowe dobranoc-

${ }^{43}$ Por. A. Szerszunowicz, Bryk z Muminków, „Kurier Poranny” 1995, nr 142, s. 7. 
ki, w którym Grażyna Kościuch i Jolanta Sztuczyńska zamieściły ponad 20 krótkich opowiadanek ${ }^{44}$.

Niektóre działania edytorskie „Naszej Księgarni” najwyraźniej służyły wzmocnieniu medialnej otoczki wokół oryginalnego cyklu T. Jansson. Taką funkcję pełnił m.in. Śpiewnik Muminków z 2004 r. w tłumaczeniu Andrzeja Tyczyńskiego ${ }^{45}$, podobny charakter miał również zbiór cytatów z baśni T. Jansson opublikowany pod tytułem Mądrości z Doliny Muminków. W 2008 r. pojawiła się Wielka księga Muminków zawierająca opowiadania autorstwa fińskich adaptatorów prozy T. Jansson w tłumaczeniu Iwony Kosmowskiej ${ }^{46}$. Kontynuację tego przedsięwzięcia stanowiły wydane rok później Nowe przygody Muminków. Równocześnie ukazały się dwa nowe zbiory opowiadań zawierające nawiązania do cyklu T. Jansson: Na lądzie i na morzu ${ }^{47}$ (2008) oraz Wielbiciele sztuki ${ }^{48}$ (2008).

Innym projektem edytorskim „Naszej Księgarni” była czterotomowa seria w twardych, lakierowanych okładkach (Muminek i kolory, $\mathrm{Mu}$ minek i pory roku, Muminek i owoce, Muminek jest duży), która powstała w 1999 r. Autorką tekstów była Heidi Bruhn, ilustracje stworzył Jari Rasi, a tłumaczenia na język polski dokonała Joanna Trzcińska-Major. Kolorowe książeczki adresowane do najmłodszych odbiorców charakteryzowały się przewagą ilustracji nad tekstem oraz wyraźnie zaznaczonym przesłaniem edukacyjnym i wychowawczym ${ }^{49}$. Wizualne podobieństwo do opisywanej serii wykazywały pozycje wydane przez Świat Książki. Cztery tomy (Muminek i przyjaciele 2004, Tajemnicza wizyta w Dolinie Muminków 2004, Nowe przygody Muminka 2005, Muminek i Mała Mi 2005) zawierały opowiadania oparte na scenariuszach japońsko-fińsko-holenderskiego filmu animowanego o Muminkach oraz fabułach tworzonych przez Larsa Janssona. W każdej części, oprócz kolorowych ilustracji, znalazła się mapa magicznej krainy oraz rysunkowe konterfekty wszystkich bohaterów zamieszczone na barwnej wklejce.

${ }^{44}$ G. Kościuch, J. Sztuczyńska, Muminkowe dobranocki, il. M. Tokarczyk, Warszawa 2002.

45 P. Kartner, Śpiewnik Muminków, Warszawa 1994, s. 28.

46 T. Saarinen, T. Mäkelä, F. Mjod, C. Alan, Wielka księga Muminków, tłum. I. Kosmowska, Warszawa 2008.

47 T. Saarinen, T. Mäkelä, F. Mjod, Na lq̨dzie i na morzu, tłum. I. Kosmowska, Warszawa 2008.

48 Tychże, Wielbiciele sztuki, tłum. I. Kosmowska, Warszawa 2008.

49 Por. M. Czernik, „Twarde” Muminki, „Guliwer” 2000, nr 1, s. 58. 
Pomimo posiadania przez „Naszą Księgarnię” praw do edycji oryginalnych historyjek o Muminkach, jak również wyłączności na ich tłumaczenie przez Irenę Chłapowską - nowe pozycje pojawiły się ze względu na umowy zawarte między poszczególnymi wydawnictwami i założoną przez siostrzenicę autorki Sophię Jansson korporację Oy Moomin Characters Ltd. Dzięki uzyskanym tą drogą licencjom powstały produkty sygnowane przez dwóch znaczących na polskim rynku książki dla dzieci i młodzieży wydawców: komiksy „Egmontu” oraz książeczki obrazkowe firmy Bertelsmann Media Polska. Pozycje tej drugiej oficyny wykorzystywały kolorowy design, jaki nadała sympatycznym trollom japońsko-fińsko-holenderska multiprodukcja filmowa z lat 90 . Ciekawym pomysłem było również przygotowanie przez Wydawnictwo Literackie książeczek zestawiających najcelniejsze cytaty wypowiadane przez poszczególnych bohaterów cyklu T. Jansson ${ }^{50}$.

Tabela 2. Wydawnictwa zajmujące się edycją książek, których bohaterami są Muminki

\begin{tabular}{|l|c|l|c|}
\hline \multicolumn{1}{|c|}{ Wydawnictwo } & $\begin{array}{c}\text { Liczba } \\
\text { pozycji }\end{array}$ & \multicolumn{1}{|c|}{ Tytuł pierwszego wydania } & $\begin{array}{c}\text { Rok } \\
\text { wydania }\end{array}$ \\
\hline „Nasza Księgarnia” & 159 & W Dolinie Muminków & 1964 \\
\hline TM Semic & 13 & Muminki (komiks) & 1993 \\
\hline $\begin{array}{l}\text { Świat Książki (Bertelsmann } \\
\text { Media Polska) }\end{array}$ & 4 & Muminek i przyjaciele & 2004 \\
\hline „Egmont” & 28 & Nowy dom Muminka & 2005 \\
\hline „Wilga” & 5 & Muminki i urodzinowy guzik & 2010 \\
\hline $\begin{array}{l}\text { Agencja Dziennikarsko- } \\
\text {-Reklamowa LiMaP } \\
\text { Marek Malarz }\end{array}$ & 2 & Muminki. Miłość, przyjaźń, rodzina & 2009 \\
\hline Wydawnictwo Literackie & 3 & Mądrości Mamy Muminka & 2010 \\
\hline
\end{tabular}

Źródło: ustalenia własne na podstawie „Przewodnika Bibliograficznego. Urzędowego Wykazu Druków Wydanych w Rzeczypospolitej Polskiej” oraz Katalogu Rozproszonego Bibliotek Polskich (KaRo).

${ }^{50}$ Wbrew wcześniejszym zapowiedziom w 2010 r. ukazały się trzy z sześciu zaplanowanych pozycji z tej serii: Mądrości Mamy Muminka, Mądrości Muminka, Mądrości Taty Muminka. W przygotowaniu są: Mądrości Małej Mi, Mądrości Włóczykija, Mądrości Ryjka. 
Ogólna liczba książkowych edycji związanych z postaciami Muminków jest imponująca i przekracza 200 pozycji (tab. 2). Szczególną rolę w tym zakresie odgrywa "Nasza Księgarnia”, jej monopol wydawniczy został przełamany w zasadzie dopiero w latach 90., i to wyłącznie w zakresie książek „okołomuminkowych”. Od tamtej pory równolegle $\mathrm{z}$ utworami $\mathrm{T}$. Jansson są publikowane coraz to nowsze kontynuacje i nawiązania noszące często znamiona swoistej dekonstrukcji oryginalnego dzieła, właściwej dla dzisiejszego postmodernistycznego poziomu odczytywania ${ }^{51}$.

\section{Nagrania dźwiękowe}

Oprócz wydań drukowanych ukazują się także edycje dźwiękowe oparte na fabułach cyklu. W 1978 r. firma Wifon przygotowała dwie kasety magnetofonowe oraz dwie płyty winylowe pt. Lato Muminków, nagrane w studiach radiowych w Warszawie i Opolu. Poszczególnych bohaterów odtwarzali znani aktorzy, m.in. Gustaw Holoubek, Mieczysław Czechowicz, Zofia Rysiówna czy Ryszarda Hanin, natomiast piosenki (tekst Bogdan Chorążuk, muzyka Tadeusz Woźniak) śpiewali m.in. Krystyna Prońko, Tadeusz Woźniak oraz harcerski zespół Gawęda ${ }^{52}$. W 2009 r. nagranie to, oczyszczone z szumów i niedoskonałości technicznych, ponownie wprowadziło na rynek w formie płyty CD Polskie Radio SA ${ }^{53}$. Polski Związek Niewidomych wydał na kasetach magnetofonowych w formie nagrania analogowego trzy książeczki: Zima Muminków (1988), Pamiętniki Tatusia Muminka (1989), Kometa nad Dolinq Muminków (1990). W 2007 r. w cyklu Mistrzowie słowa opracowano audiobook W Dolinie Muminków w interpretacji Krzysztofa Kowalewskiego. Jego wydawcą była Agora i Dom Wydawniczy „Bellona”.

${ }^{51}$ M. Kylmänen, Boom muminkowy w Finlandii w latach dziewięćdziesiątych. Jak telewizja i wielki biznes zmieniły Muminki i status książek Tove Jansson o Muminkach?, tłum. B. Lubich-Pyrzowska, [w:] Świat Muminków..., s. 103-105.

52 Por. E. Bisewska, Dom poza czasem. Jeszcze raz o rodzinności w „Muminkach” Tove Jansson, [w:] Przeboje edukacji polonistycznej, pod red. D. Michułki, Wrocław 2001, s. 50; K. Masłoń, Gościna w domu z wieżyczkq, „Rzeczpospolita” 2001, nr 162, s. 14; bmj, Lato Muminków, „Trybuna Ludu” 1979, nr 126, s. 358.

53 Por. M. Kuźmiński, Wcale nie głupole, „Tygodnik Powszechny” 2010, nr 3, s. 38. 


\section{Adaptacje filmowe i sceniczne}

Konsekwencją popularności utworów T. Jansson są liczne adaptacje jej tekstów literackich na potrzeby teatru i filmu. W Polsce pierwszy taki spektakl sceniczny został zrealizowany na deskach łódzkiego teatru lalkowego „Arlekin” w 1977 r. W końcu lat 70. nowe przedstawienia pojawiały się w różnych częściach Polski, potwierdzając duże zainteresowanie baśnią o Muminkach najmłodszych czytelników. Większość recenzji nie była jednak jednoznacznie pozytywna: kwestionowały one poziom widowisk, zwracały uwagę na ich wtórność i sprowadzenie perypetii tylko i wyłącznie do wymiaru ludycznego ${ }^{54}$. Należy jeszcze wspomnieć o przedstawieniu w krakowskiej „Grotesce” z 1978 r., na którym pojawiła się sama pisarka, a jego scenariusz był z nią wcześniej konsultowany ${ }^{55}$.

Pod koniec lat 70. w łódzkim studiu filmowym Se-ma-for rozpoczęto realizację kilkudziesięcioodcinkowego serialu o Muminkach według scenariusza Marii Kossakowskiej i Lucjana Dębińskiego ${ }^{56}$. Projekt ów wygrał z ofertami wielu uznanych wytwórni światowych, co należy uznać za duży sukces polskiej kinematografii. Zastosowano w nim nowoczesne w owym czasie rozwiązania techniczne, m.in. specjalne trójwymiarowe triki z użyciem soczewek. Z przygotowanych wówczas materiałów zmontowano także filmy, które trafiły na ekrany kin $^{57}$. Swoistą kontynuację tego przedsięwzięcia stanowiła produkcja z 2010 r., zrealizowana w technologii 3D w reżyserii Marii Lindberg ${ }^{58}$.

\section{Muminki w dyskursie naukowym i kryłycznoliterackim}

Popularność książek o Muminkach można przeanalizować, śledząc recepcję tego cyklu w polskiej prasie. Uwagę zwraca duża różnorodność

${ }^{54}$ Por. T. Soldenhoff, Dwie adaptacje , „Odgłosy” 1978, nr 12, s. 10 (o przedstawieniu w Łodzi); K. Kucharski, Zniechęcanie do czytania albo Muminki w Wałbrzychu, „Gazeta Robotnicza" 1978, nr 68, s. 3.

55 D. Jakubiec, Muminki w Krakowie, „Dziennik Polski” 1978, nr 221, s. 3.

${ }^{56}$ Był on także, obok Krystyny Kulczyckiej, Dariusza Zawilskiego i Jadwigi Kudrzyckiej, reżyserem tego serialu.

57 Szczęśliwe dni Muminków (1983), Zima w Dolinie Muminków (1986) czy kilkanaście lat później Lato Mumików (2009).

${ }^{58}$ Kometa nad Dolinq Muminków (2010), kraje produkcji: Polska, Wielka Brytania, Finlandia. 
artykułów poświęconych skandynawskim trollom. Zróżnicowanie to dotyczy poruszanej tematyki (kwestie stricte literackie, nawiązania, filozofia, pedagogika), jak również formalnej postaci prasowych wypowiedzi (notka, sprawozdanie, esej, recenzja, wywiad, polemika). Z pewnością konsekwencją tego wielogłosu jest obecność publikacji poświęconych Muminkom w szerokim spektrum pism - od popularnych dzienników (np. „Gazeta Wyborcza”, „Superexpress”, „Kurier Polski”), periodyków społeczno-kulturalnych (np. „Tygodnik Powszechny”, „Przekrój”, „Polityka”), prasy dziecięcej („Świerszczyk”, „Płomyk”), po czasopisma literackie (np. „Twórczość”, „Guliwer”), popularnonaukowe („Wiedza i Życie”) czy naukowe („Bez Porównania”).

Chronologicznie pierwszą wzmianką o Muminkach w polskiej prasie była dość formalna recenzja odnotowująca pojawienie się na polskim rynku wydawniczym książki W Dolinie Muminków z 1964 r., zamieszczona na łamach „Nowych Książek”. Halina Skrobiszewska zinterpretowała tu fabułę w konwencji uwspółcześnionej baśni ${ }^{59}$. Podobnie zresztą jak później Krystyna Kuliczkowska ${ }^{60}$, doszukiwała się źródeł popularności w udanym mariażu kompozycji baśniowej z realistyczną tematyką poruszającą istotne problemy społeczne i moralne. Halina Skrobiszewska umieściła historyjkę o Muminkach obok słynnych klasycznych tytułów literatury dla dzieci i młodzieży, takich jak Kubuś Puchatek czy Alicja w Krainie Czarów, zalecała lekturę czytelnikom 8-10-letnim i domagała się przetłumaczenia całego ośmiotomowego cyklu, a następnie ponownej jego edycji ${ }^{61}$. W początku lat 70. (a więc po kilku wydanych wcześniej tomikach) rodzima krytyka literacka zwróciła większą uwagę na opowieści o skandynawskich trollach. Milowym krokiem był w tym względzie obszerny esej Anny Kamieńskiej Traktat o historii Muminków opublikowany w czasopiśmie „Twórczość”62. Zdaniem autorki był on „próbą znalezienia nowego języka krytycznego w stosunku do literatury dziecięcej”, ale już samo pojawienie się artykułu na temat utworu adresowanego do dzieci w tak poważanym periodyku stanowiło swoistą nobilitację i wyraźny sygnał, że stoi on na wysokim poziomie artystycznym. Eseistka poruszyła sze-

59 H. Skrobiszewska, Wszystkiego po trochu, „Nowe Książki” 1964, nr 23, s. 1075.

${ }^{60}$ K. Kuliczkowska, Fantastyka i metafora, [w:] Baśń i dziecko, pod red. H. Skrobiszewskiej, Warszawa 1978, s. 66; za: E. Konieczna, Baśń w literaturze i filmie, Kraków 2005, s. 33-34.

${ }^{61}$ H. Skrobiszewska, Książki naszych dzieci, czyli o literaturze dla dzieci i młodzieży, Warszawa 1971, s. 248-250, 252.

${ }^{62}$ A. Kamieńska, Traktat o historii Muminków, „Twórczość” 1971, nr 3, s. 84-90. 
reg płaszczyzn interpretacyjnych, poczynając od kwestii ontologicznej, bycia w czasie Muminków, a kończąc na walorach językowych utworu, sposobie kreacji humoru na pograniczu fantastyki i realności oraz poezji tkwiącej „podskórnie” w nastawieniu postaci do świata przedstawionego, w „dziwności” i „tajemniczości” literackiego uniwersum. Jak podkreśla Teresa Brzeska-Smerkowa, tekst A. Kamieńskiej opowiada się zdecydowanie za wartościami rodzinnymi, stanowi apologię mieszczańskiego domu będącego dla dziecka „pierwotnym rajem” i w tym sensie jest opozycyjny w stosunku do powszechnie wtedy obowiązującej doktryny socjalistycznej ${ }^{63}$. Ostoja wartości nie kłóci się przy tym z przyjemnością posiadania, poszczególne rzeczy istnieją bowiem „po to, aby życie groźne i niepewne uczynić bardziej bezpiecznym i zrozumiałym"64. Wielką rolę pedagogiczną przypisano także Mamie Muminka, przedstawiając jej zabiegi wychowawcze obrazowo jako mądrość (a co za tym idzie - dobre wychowanie), będącą sumą dobroci i miłości. Esej został napisany prostym, zwięzłym, jakby nieco „dziecięcym” językiem, w czym przejawiało się pokrewieństwo literackie z opisywanym dziełem ${ }^{65}$. Traktat... stał się swoistym drogowskazem, do którego w ten lub inny sposób odnosiły się kolejne prace krytyczne poświęcone twórczości T. Jansson. Jego fragmenty były wielokrotnie cytowane w kolejnych artykułach, czy też nawet przedrukowywane we fragmentach na łamach innych czasopism ${ }^{66}$. Liczne wątki zostały twórczo rozwinięte w późniejszych publikacjach, należy przy tym zauważyć, że w niektórych przypadkach wywody miały charakter specyficznie polski, odnoszący się do panującego w kraju wzorca światopoglądowego ${ }^{67}$. Bezpośrednią polemikę podjęła na łamach „Twórczości” Jadwiga Żylińska ${ }^{68}$. W poszukiwaniu tożsamości Muminków przedstawiła ona pochodzenie trolli, które w wierzeniach skandynawskich zajmowały poczesne miejsce, oraz pokrewnych im istot związanych z folklorem germańskim i anglosaskim. W licznych księgach, mapach i zapisach sądowych potwierdziła historyczność postaci, podkreślając tym samym

${ }^{63}$ Por. T. Brzeska-Smerkowa, dz. cyt., s. 35-36.

${ }^{64}$ A. Kamieńska, dz. cyt., s. 86.

65 Por. T. Brzeska-Smerkowa, dz. cyt., s. 36.

66 Por. np. „Płomyk” 1974, nr 6, s. 171-173; „Guliwer” 1994, nr 2, s. 12-13.

67 Sytuacja uległa zmianie w ostatnich latach. Świadectwem zainteresowania zagranicznymi badaniami jest referat H. Dymel-Trzebiatowskiej, Muminki - na zawsze!, „Guliwer" 2007, nr 3, s. 28-35, poświęcony m.in. rozważaniom szwedzkich filologów: Marii Nikolajevej, Torstena Rönnerstranda, Janiny Orlov.

68 J. Żylińska, dz. cyt., s. 162-164. 
ewolucyjny charakter ich aktualnego ustroju społecznego ${ }^{69}$. W owych aluzjach do „klasy średniej”, „małej stabilizacji” czy „ustroju monarchistycznego" ukrywa się zresztą szerszy dialog światopoglądowy wskazujący na potencjał polityczny, jaki w owym okresie towarzyszył niejednemu dyskursowi krytycznoliterackiemu. Czy Muminki były jakkolwiek powiązane z polską rzeczywistością polityczną? Agnieszka Osiecka w książce Szpetni czterdziestoletni zalicza te utwory, łącznie z Kubusiem Puchatkiem i Małym księciem, do lektur kultowych, towarzyszących kolejnym „odwilżom"70. Marek Arpad Kowalski twierdzi jednak, że Muminki były apolityczne: „Kiedy u progu zimy przyszedł stan wojenny w Polsce, podziemna «Solidarność» rzuciła hasło: «Zima wasza, wiosna nasza». A żartownisie rozwinęli je «...a lato Muminków»"71.

W wielu artykułach Muminki były przyrównywane do obecnych w kulturze skandynawskiej trolli ${ }^{72}$, a często nawet utożsamiane ze swojskimi krasnoludkami czy ubożętami ${ }^{73}$. Stanisław Zieliński przypomina w tym względzie nieocenionego Jana Chryzostoma Paska, który twierdził, „że w całym królestwie szwedzkim i niektórych prowincjach duńskich krasnoludkami tak robią jako niewolnikami w Turczech, i co im każą, to czynić muszą, i nazywają ich spiritus familiares"74. Ryszard Waksmund poświęcił swoją wypowiedź tradycyjnym protoplastom rodu Muminków. Wskazał przy tym na wyraźne różnice między demonicznymi mieszkańcami Gór Skandynawskich a sympatycznymi postaciami z cyklu powieściowego:

W plastycznej ewolucji Muminka był taki okres, kiedy zmieniła się jego fizjonomia - ze złośliwego ostronosego zwierzątka przekształcił się w istotkę o krągłych kształtach i zupełnie odmiennym usposobieniu. [...] Jansson odbiera im demoniczne atrybuty pod każdym względem, także i pod tym, że odgradza na ogół swych bohaterów od świata ludzi, co pozbawia jej fabuły napięć charakterystycznych dla baśni ludowej ${ }^{75}$.

69 Tamże.

${ }^{70}$ A. Osiecka, Szpetni czterdziestoletni, Warszawa 1985, s. 94.

${ }^{71}$ M. A. Kowalski, Rok Muminków, „Trybuna Śląska” 1998, nr 148, s. 10.

72 O szczęśliwych, czyli wokół traktatu o historii Muminków, „Radio i Telewizja” 1980, nr 20, s. 24.

${ }^{73}$ L. Błaszczyk, Pożegnanie Tove Jansson, „Poradnik Bibliotekarza” 2001, nr 10, s. 20.

${ }^{74}$ S. Zieliński, Słonecznie, swojsko i przytulnie, „Nowe Książki” 1977, nr 11, s. 56-58, opublikowane także jako rozdział książki tegoż, Gawędy z pretekstem, Warszawa 1978, s. 395-400.

75 R. Waksmund, Protoplaści Muminków. Przyczynek do trollologii i genologii literackiej, [w:] Świat Muminków..., s. 77. 
Tak więc Muminki realizują popularny w naszych czasach wzorzec baśni literackiej, która cechuje się, między innymi, zdolnością przekształcenia przeróżnych motywów w taki sposób, że powstający świat przedstawiony odznacza się całkowitą autonomią w stosunku do pierwowzoru tkwiącego w ludowych wierzeniach. W utworach takich większe znaczenie ma psychologiczny rys poszczególnych postaci oraz swoista fizyczna egzemplifikacja metafory ${ }^{76}$.

\section{a) Kategorie strachu oraz filozofia równowagi}

Charakterystycznym nurtem krytycznego dyskursu było omawianie wątków katastroficznych w opowieściach o Muminkach. W sielskiej dolinie nie zawsze bowiem jest „słonecznie, swojsko i przytulnie”, jak chciałby S. Zieliński ${ }^{77}$. Większość tomów opowieści obfituje w niebezpieczne przygody, a groźne żywioły czają się za progiem okrągłego domostwa ${ }^{78}$. Już pierwszy tom opisuje apokaliptyczną powódź, w innych pojawia się sztorm, trąba powietrzna czy spadająca kometa. Przerażenie wzbudza długa skandynawska zima, w czasie której ocknął się nieoczekiwanie główny bohater, po raz pierwszy stykając się z problemem śmierci. W świecie Muminków pojawia się też złowroga Buka, uosobienie zła i samotności. Ostatni tom serii - Dolina Muminków w listopadzie - w dużym stopniu jest wykładnikiem egzystencjalnej filozofii pisarki. Sytuacja fabularna (liczni bohaterowie trafiają do Doliny Muminków, ale znajdują tylko pusty dom i są mimowolnie skazani na zamieszkiwanie ze sobą nawzajem i stworzenie nowych relacji międzyosobowych) jako żywo przypomina słynną sztukę Jeana-Paula Sartre’a Przy drzwiach zamkniętych i aż ciśnie się na usta znany komentarz „Piekło to Inni”79. Równocześnie ów smutek przebijający z kolejnych utworów jest dawkowany bardzo umiejętnie, istnienie zagrożeń i rzeczy ostatecznych wydaje się stonowane przez rozsądne i wyważone stanowiska bohaterów wobec otaczającej rzeczywistości, a nawet ich „heroiczną” dawkę humoru. „Tove Jansson nie lęka się

76 J. Szczepanowska, Charakterystyka świata przedstawionego w cyklu Tove Jansson o Muminkach, „Zeszyty Naukowe Wydziału Humanistycznego Uniwersytetu Gdańskiego. Studia Scandinavica" 1983, nr 6, s. 123-139.

77 Za: T. Brzeska-Smerkowa, dz. cyt., s. 39.

78 Por. Z. Beszczyńska, Nie szkodzi, że kometa, „Guliwer” 1995, nr 2, s. 25; M. Olszewski, Klucz do świata, „Gazeta Wyborcza” 2004, nr 218 - dodatek „Książki”, s. 1.

79 W. Orliński, Za progiem domu Muminków, „Gazeta Wyborcza” 1997, nr 287, s. 20. 
ukazywać dziecku niebezpieczeństw, nigdy jednak nie dopuszcza do konsekwencji, do których mogą one doprowadzić. Dba, aby przedwcześnie nie ujawnić smutnych prawd, z którymi musi zetknąć się człowiek dorosły" ${ }^{80}$. Odmiennie zatem niż Kubuś Puchatek, Muminki wydają się opowieścią trwającą w idylli dzieciństwa. Jej ludzki wymiar nie polega przy tym na braku wstrząsów i lęków, ale raczej na swoistej apoteozie codzienności rozumianej jako pewna, spokojna i nasycona sensem trwania niezmienność ${ }^{81}$. Kwintesencją pedagogicznej postawy fińskiej pisarki jest opublikowany w Polsce w 1978 r. jej artykuł Bezpieczeństwo i strach w ksiq̨żkach dla dzieci ${ }^{82}$.

Specyficzny egzystencjalny wydźwięk muminkowych historii zauważyła już A. Kamieńska we wspominanym Traktacie..., dyskusję na ten temat prowadzili m.in. Małgorzata Baranowska ${ }^{83}$, Jolanta Hartwig-Sosnowska $^{84}$ czy Michał Błażejewski ${ }^{85}$. Ten ostatni wiąże opowieści o trollach z pojęciem lęku pojawiającym się także w literaturze psychologicznej, wskazując na ich biblioterapeutyczny potencjał. Elementy nowoczesnej psychologii zawarte $\mathrm{w}$ serii interesujących nas książek były kolejnym kontekstem interpretacyjnym rozwijanym w ramach krytycznego dyskursu. W popularnych baśniach wielu badaczy znalazło odniesienia do nauk Carla Gustava Junga ${ }^{86}$ czy Brunona Bettelheima ${ }^{87}$. Interesującą wykładnię roli Mamy Muminka w duchu krytyki feministycznej, opartą jednak na elementach psychoanalizy Freuda, przeprowadza Kinga Dunin: „Mama Muminka jest istotą kompletnie aseksualną. Jeśli nawet jest boginią matriarchalnego świata, to jest to bogini wykastrowana. [...] Nie jest matką, która rodzi, tylko mamusią. [...] Przeniknięty mamusiowatym fan-

80 J. Hartwig-Sosnowska, One istnieją na pewno..., s. 19.

81 Por. G. Leszczyński, Książka dla dziecka a współczesne nurty literackie, [w:] tenże, Literatura i książka dziecięca. Słowo - obiegi - konteksty, Warszawa 2003, s. 112-113.

82 T. Jansson, Bezpieczeństwo i strach w książkach dla dzieci, tłum. T. Chłapowska, „Literatura na Świecie" 1978, nr 6, s. 6-9.

83 M. Baranowska, Od Różdżki Złotej do Muminków, „Wiedza i Życie” 1978, nr 4, s. 84.

${ }^{84}$ J. Hartwig-Sosnowska, One istniejq na pewno..., s. 19.

85 M. Błażejewski, Przestrzenie biblioterapii, „Albo albo” 2003, nr 4, s. 35-45; por. H. Dymel-Trzebiatowska, dz. cyt., s. 29-30.

${ }^{86}$ O. Tokarczuk, Muminki - droga do dojrzałości, „Problemy Opiekuńczo-Wychowawcze" 1993, nr 10, s. 443-449.

${ }^{87}$ J. Papuzińska, Dziecko w świecie emocji literackich, Warszawa 1996, s. 9-18; K. Krasoń, Antropomorfizowany obraz interakcji jako literacka propedeutyka więzi, [w:] Sezamie otwórz się! Z nowszych badań nad literatura dla dzieci i młodzieży, pod red. A. Baluch, K. Gajdy, Kraków 2001, s. 110-122. 
tazmatem świat Muminków jest tak przytulny między innymi dlatego, że wygnany został z niego Eros" ${ }^{\prime 8}$.

\section{b) W kręgu psychologii, terapii i poznania}

Wielokrotnie zwracano uwagę na wartość terapeutyczną omawianych tomików, wynikającą z faktu ukazywania postaci emanujących optymizmem, otwartością i tolerancją wobec innych ${ }^{89}$. Takie postawy nie miały przy tym znamion moralizatorstwa, były raczej „słowami zachęty, otuchy czy pocieszenia"90. Bohaterowie zostali obdarzeni wyrazistymi cechami charakteru, co pozwalało dość jednoznacznie postrzegać ich nastawienie do życia. Tym samym łatwiej było wyeksponować pisarce konkretne pozytywne wartości. Mało tego, autorka poruszyła trudne zagadnienie problemów psychologicznych człowieka. Utwory te w wielu fragmentach przypominają powieść o dorastaniu. Droga do psychicznej dojrzałości wiedzie przez liczne epizody fabuły odnoszące się do kolejnych etapów inicjacji ${ }^{91}$. W tomie Tatuś Muminka i morze opisano „kryzys wieku średniego" ${ }^{92}$ związany raczej z dorosłą psychologią, niemniej jednak nierzadko w pośredni sposób obecny także w doświadczeniach dziecięcych. Wiele osobowości przewijających się przez karty książek ma charakter neurotyczny ${ }^{93}$ : Filifionka jest pełna katastroficznych lęków, Włóczykij rozpaczliwie pragnie wolności bez granic, Paszczak stara się wypełnić wewnętrzną pustkę przez przyjmowanie określonych ról, Nini jest odrzuconym dzieckiem cierpiącym na syndrom sieroty itp. Równocześnie wyraziste typy charakterologiczne wchodzą ze sobą w określone relacje, które mogą być traktowane niemal jako archetypy zachowań psychologicznie istotnych. Katarzyna Krasoń podaje szereg przykładów takich więzi, łączących rodziców i dzieci (Tata i Mama Muminka - Muminek, rodzina Homków) czy przyja-

${ }^{88}$ K. Dunin, Co Mamusia ma w torebce?, „Tygodnik Powszechny” 2007, nr 15, s. 17.

${ }^{89}$ Por. np. S. Zieliński, dz. cyt.; K. M. Bujwid, Czy warto kochać Muminki?, „Nowe Książki" 1976, nr 8, s. 39-40; J. Hartwig-Sosnowska, Muminki: akceptacja świata, [w:] taż, Wyobraźnia bez granic, Warszawa 1987, s. 175-197.

${ }_{90}$ M. Bojarska, Kochaj bliźniego jak Muminka swego, „Nowe Książki” 1980, nr 24, s. $16-18$.

91 O. Tokarczuk, Muminki - droga do dojrzałości..., s. 443-449; Ł. Piekarska-Duraj, Dom w dolinie, „Autoportret” 2004, nr 4, s. 64-65.

92 J. Wieczerska, Prezent dla paru generacji, „Czas” 1977, nr 23, s. 25.

93 J. Papuzińska, Dziecko w świecie emocji..., s. 12. 
ciół (Muminek i Włóczykij, Muminek i Panna Migotka) ${ }^{94}$. Jednym z najważniejszych motywów powieści jest dom rodzinny ukazany nie tylko jako okiełznane i uporządkowane terytorium odznaczające się oryginalnymi właściwościami (np. okrągła fasada, ozdoby na balustradzie, kształt pieca, ściany wymalowane na niebiesko) ${ }^{95}$, ale przede wszystkim jako miejsce wspólne kochającej się rodziny ${ }^{96}$. Barwny świat doliny Muminków powoduje, że zainteresowanie budzi zarówno perypetia, jak i poszczególni bohaterowie ${ }^{97}$ oraz sceneria, w której toczy się akcja opowieści. Przyroda nie pełni przy tym tylko i wyłącznie funkcji tła, ale, jak u większości twórców skandynawskich, staje się integralnym elementem akcji, miejscem mentalnej emigracji czytelnika i projekcją wrażeń samej autorki z dzieciństwa spędzonego na wyspie w Zatoce Fińskiej ${ }^{98}$.

Opisany powyżej potencjał wartości filozoficznych, literackich, poznawczych i wychowawczych wywołał popularność Muminków wśród nauczycieli ${ }^{99}$. W kwartalniku „Guliwer” zamieszczono wiele artykułów świadczących o fascynacji dorosłych opowiadaniami T. Jansson. Pokazują one moc wyobraźni tkwiącą w tej lekturze, która stanowi niewyczerpany arsenał pomysłów dla twórczych zabaw ${ }^{100}$. Wydaje się, że ten spójny, wirtualny świat może w równy sposób stymulować zachowania zarówno dzieci, jak i dorosłych ${ }^{101}$. Stąd trudno się dziwić, że pojawiły się propozycje wykorzystania fabuły o sympatycznych trollach do zabaw edukacyjnych prowadzonych w szkołach, bibliotekach czy domach rodzinnych ${ }^{102}$.

94 K. Krasoń, dz. cyt.

95 Ł. Piekarska-Duraj, dz. cyt., s. 64-65; A. Baluch, Muminki - próba topoanalizy, [w:] Świat Muminków..., s. 23-28.

96 E. Bisewska, Dom poza czasem..., s. 49-60.

97 Por. np. taż, Muminki Tove Jansson - studium wybranych problemów, Gdańsk 1994; J. Ługowska, Negatywni bohaterowie cyklu Tove Jansson wobec tradycyjnego wzorca baśni dla dzieci, [w:] Świat Muminków..., s. 57-66; K. Urba, Charakterystyka bohaterów Tove Jansson - próba klasyfikacji, [w:] tamże, s. 73-75; D. Karecka, Hatifnatowie, tajemnica, rytuały, „Guliwer” 2008, nr 2, s. 62-68.

98 Z. Hulko, Krajobraz w prozie Tove Jansson, „Bez Porównania” 2007, nr 5, s. 9-41; M. Strzałkowska, Każdy jest, jaki jest, „Polityka” 2001, nr 28, s. 51; P. Huelle, dz. cyt., s. 17.

99 A. Maćkowska, O Dolinie Muminków i jej Autorce, „Warsztaty Polonistyczne” 2001, nr 4, s. 17-31.

100 M. Machnowska, Pokochać Muminki, „Guliwer” 1994, nr 2, s. 43; M. Kulik, W Dolinie Muminków. Scenariusz zabawy literackiej, „Guliwer” 2002, nr 4, s. 72-73.

101 J. Wieczerska, Zabawa, klucz, pociecha, „Guliwer” 1994, nr 3, s. 40-41; Z. Beszczyńska, dz. cyt., s. 26.

102 M. Kulik, dz. cyt., s. 72-73; A. Pacuszka, Ach te Muminki, „Poradnik Bibliotekarza” 1998, nr 2, s. 27-32; E. Bisewska, Spotkanie w Dolinie Muminków, „Poradnik Biblioteka- 
W nawiązaniu do obecnego w fińskiej sadze świata wartości Olga Tokarczuk zaproponowała zajęcia przypominające psychoterapeutyczny seans ${ }^{103}$.

\section{c) Publikacje okolicznościowe}

Muminki są obecne na łamach prasy nie tylko w związku z prowadzonymi dyskusjami krytycznoliterackimi czy zamieszczaniem publikacji o charakterze edukacyjnym i wychowawczym. Trzeba pamiętać, że przede wszystkim opowieści o nich stanowią ważne ogniwo współczesnej kultury i jako takie są przedstawiane w szerokim aspekcie ukazującym zarówno treść opowiadań, życiorys autorki, jak i całą otoczkę związaną z ich intersubiektywną obecnością.

Stosunkowo sporo było wzmianek o charakterze okolicznościowym. W związku z przyznaniem autorce Muminków Orderu Uśmiechu w $1975 \mathrm{r}^{104} \mathrm{w}$ prasie pojawiły się krótkie notki na ten temat ${ }^{105}$. W $1978 \mathrm{r}$., korzystając z wizyty T. Jansson w naszym kraju, opublikowano kilka krótkich wywiadów z nią. Dotyczyły one jej twórczości oraz świeżo podpisanego kontraktu z łódzką wytwórnią filmową ${ }^{106}$. Podobną rozmowę „nie tylko o Muminkach" z tłumaczką T. Chłapowską opublikował „Guliwer” $\mathrm{w}$ monograficznym zeszycie wydanym $\mathrm{z}$ okazji osiemdziesiątych urodzin pisarki, a zarazem trzydziestolecia pierwszego wydania jej książki w Polsce ${ }^{107}$. W tym jubileuszowym numerze ukazało się ponadto kilka artykułów i wypowiedzi traktujących o prozie T. Jansson oraz przykłady jej korespondencji z czytelnikami. Śmierć pisarki w 2001 r. dała powód do przypomnienia jej literackich dokonań. W tym okresie pojawiły się liczne teksty wspomnieniowe zawierające słowa podziękowań za piękne i poruszające utwory oraz komentarze podsumowujące spuści-

rza" 1994, nr 6, s. 14-15; G. Walczewska-Klimczak, Czy w Dolinie Muminków potrzebne sq szkoły?, „Guliwer” 1994, nr 5, s. 40-47.

103 O. Tokarczuk, Muminki. Droga do dojrzałości, Wałbrzych 1994; zob. taż, Muminki. Droga do dojrzałości, „Guliwer” 1994, nr 4, s. 35-38.

${ }^{104}$ Wręczenie Orderu Uśmiechu nastąpiło dopiero 2 grudnia 1976 r. w polskiej ambasadzie w Helsinkach.

105 Order Uśmiechu, „Nowe Książki” 1975, nr 20; Dzieci dorosłym. Nowi kawalerowie Orderu Uśmiechu, „Kurier Polski” 1975, nr 199; za: T. Brzeska-Smerkowa, dz. cyt., s. 37-38.

106 T. Jansson, rozm. przepr. L. R. Nowak, „Przekrój” 1978, nr 1712, s. 18.

107 B. Tylicka, T. Chłapowska, Nie tylko o Muminkach, „Guliwer” 1994, nr 2, s. 14-18. 
znę twórczą „córki rzeźbiarza”108. Okolicznościowe teksty o wymownym tytule ukazały się także 5 lat po śmierci autorki Lata Muminków ${ }^{109}$. Całość uzupełniają okazjonalnie drukowane reportaże z pobytu w fińskim parku rozrywki poświęconym bohaterom opowiadań T. Jansson ${ }^{110}$, jak również z wizyt w Muzeum Muminków mieszczącym się w miejskiej bibliotece w Tampere ${ }^{111}$.

W 1994 r. w Gdańsku miało miejsce dwudniowe sympozjum poświęcone twórczości T. Jansson, które zgromadziło wielu badaczy z Polski, Litwy i Finlandii. To odbywające się pod patronatem Ministerstwa Kultury i Sztuki oraz Ambasady Republiki Finlandii spotkanie uświetniły dwie znane literatki - Małgorzata Musierowicz i Joanna Kulmowa. Pokłosiem dwudniowych obrad był tom zawierający 19 referatów opisujących kluczowe zagadnienia treści, interpretacji oraz recepcji twórczości T. Jansson $^{112}$. Publikacja została uzupełniona o wzruszającą korespondencję między fińską pisarką a uczestnikami sesji.

\section{Podsumowanie}

W porównaniu do innych współczesnych bestsellerów literatury młodzieżowej i dziecięcej (np. Harry Potter J. K. Rowling) w przypadku Muminków zorganizowano zdecydowanie mniej spektakularnych akcji promocyjnych. Niezwykle popularni w latach 70. i 80. bohaterowie u progu nowej rzeczywistości ekonomicznej nie zostali całkowicie wyparci przez

108 L. Błaszczyk, dz. cyt., s. 20; G. Leszczyński, Pożegnanie, „Guliwer” 2001, nr 4, s. 87-88; K. Masłoń, Budujcie tratwę przed potopem, „Rzeczpospolita” 2001, nr 149, s. 14; tenże, Opustoszała tratwa Muminków, „Magazyn Literacki Książki” 2001, nr 7, s. 9; D. Nowak, Muminki płaczq, „Przekrój” 2001, nr 27, s. 32-33; M. Wojtczuk, Osierocone Muminki, „Gazeta Wyborcza” 2001, nr 149, s. 2; J. Wieczerska, Świat dobrych egoistów, „Dziennik Bałtycki” 2001, nr 156, s. 14.

109 H. Dymel-Trzebiatowska, dz. cyt., s. 28-35; M. Wojtyszko, Muminki wiecznie żywe, „Dziennik” 2006, nr 58, s. 37.

110 Zlokalizowanym w niewielkim miasteczku Naantali na zachodnim wybrzeżu. Por. E. Świerżewska, Dolina Muminków w... lipcu, „Guliwer” 2002, nr 4, s. 44-45.

111 B. Wróblewska, Z wizytą u Muminków, „Gazeta Wyborcza. Magazyn” 2001, nr 173, s. 26-27; E. Świerżewska, dz. cyt., s. 44-45; M. Pajunen, W świecie Tove Jansson, „Guliwer” 2002, nr 4, s. 45-50.

112 Świat Muminków... Wydarzenie to przedstawił A. Chojecki, Muminki, czyli o łatwości bycia literaturoznawcq, „Tytuł” 1994, nr 2, s. 218-220; por. także J. Papuzińska, Starość bliska dzieciństwu, „Gazeta Wyborcza” 1994, nr 137 - dodatek „Gazeta o Książkach” nr 6, s. 13. 
disnejowskie kreskówki, „wszelkiego rodzaju Witch'e i Teletubisie”113. Ciągle aktualne wydaje się stwierdzenie Joanny Papuzińskiej, że „Muminki w Polsce nie utraciły swej szlachetności i godności. Nikt na razie jeszcze nie jeździ na nich na oklep, nie używa jako gruszki do boksowania ani też nie wyciera nimi nosa"114.

Fenomen popularności Muminków w naszym kraju przejawia się w wielu aspektach. Pozycje z tego cyklu są jednymi z częściej wznawianych utworów literatury dla dzieci i młodzieży. Istnienie sympatycznych trolli w codziennej kulturze jest wielopoziomowe. Świadczą o tym recenzje poszczególnych tomów, liczne adaptacje teatralne oraz filmowe, a także obecność tych bohaterów na stronach polskiego Internetu ${ }^{115}$. Fascynacja stworzonymi przez T. Jansson postaciami może wynikać z tęsknoty za pierwiastkiem niezwykłości w naszym otoczeniu ${ }^{116}$ oraz za życiem opartym na zasadzie wzajemnej tolerancji i miłości ${ }^{117}$.

Ważne miejsce w piśmiennictwie na temat tych utworów zajmuje komparatystyka. Dzieła T. Jansson zestawiano z klasycznymi pozycjami powszechnej i rodzimej literatury dziecięcej, podkreślano także ich osobisty charakter ${ }^{118}$. Autobiografia pisarki - Córka rzeźbiarza ${ }^{119}$ - ujawnia szereg podobieństw między bohaterami i epizodami z książek o Muminkach a faktycznymi postaciami i zdarzeniami z życia T. Jansson ${ }^{120}$.

Należy zwrócić uwagę, że w ostatnich latach liczba artykułów prasowych poświęconych Muminkom i ich autorce wyraźnie wzrosła, a tematyka ta pojawia się też w licznych, często symbolicznych kontekstach ${ }^{121}$, co świadczy o niezwykłej żywotności książki, jak również wskazuje na

113 Por. M. Starczewski, Trolle wróciły, „Tygodnik Ostrołęcki” 2006, nr 37, s. 20.

114 J. Papuzińska, Muminkalia gdańskie, „Guliwer” 1994, nr 4, s. 46-48.

115 Wpisując słowo „Muminki” w popularną wyszukiwarkę internetową Google, otrzymamy informacje o istnieniu setek tysięcy polskojęzycznych stron związanych z tym terminem. Samo hasło „Muminki” w popularnej Wikipedii liczy około 20 tys. znaków i ma kilkanaście hipertekstowych odsyłaczy.

116 P. Huelle, dz. cyt., s. 17.

117 M. Wojtyszko, dz. cyt., s. 37.

118 J. Olech, Mała Mi, „Tygodnik Powszechny” 2003, nr 15, s. 15.

119 T. Jansson, Córka rzeźbiarza, Gdańsk 1999. Por. M. Kisilowska, Prawdziwe oblicze mamy Muminka, „Guliwer” 2000, nr 1, s. 58-60.

${ }_{120}$ Por. dociekania J. Olech, Mała Mi..., s. 15.

${ }^{121}$ Warto w tym względzie przytoczyć tytuł artykułu J. Ługowskiej, Muminki się ciesza, że Ryjka powiesza, [w:] W zwierciadle języka i kultury, pod red. J. Adamowskiego, S. Niebrzegowskiej, Lublin 1999, s. 455-463, koncentrującego się na stylistyce popularnych dziecięcych wyliczanek, traktowanych jako zjawisko z pogranicza folkloru i współczesnego slangu młodzieżowego. 
charakterystyczną w dzisiejszej kulturze tendencję do totalizacji określonej marki literackiej ${ }^{122}$. Z całą pewnością o sukcesie tej serii w znacznym stopniu zadecydowała jej autentyczność, sprawiająca, że jest to fascynująca lektura zarówno dla dzieci, jak i dorosłych. Przekazywanie wiedzy o niej ma zatem charakter dialogu międzypokoleniowego i nie ogranicza się tylko do dziecięcej perspektywy.

\section{Tove Jansson's Moomins on Polish publishing market \\ Abstract}

Moomintroll stories by Tove Jansson were brought to Poland by Wojciech Żukrowski. Their publisher - the same for almost 50 years - is "Nasza Księgarnia." First book translated into Polish from this fairy-tale series (Finn Family Moomintroll) was published in 1964. It is worth mentioning that individual volumes were published in our country in a different order than the order created by the author and more to that, many years after the date of their first edition. Popularity of these books is well demonstrated by the number of reprints and adaptations - all with accompanying lively response from literary critics. The article discusses such issues connected to the presence of T. Jansson's Moomins series on the Polish publishing market as: editions, translations, graphic design, continuations, adaptations for film and stage. Opinions of literary critics on these works were also analyzed.

122 Por. M. Zając, Promocja ksiq̨żki dziecięcej, Warszawa 2000, s. 163-166. 